\title{
ГЕОАРХЕОЛОГИЧЕСКИЕ ИССЛЕДОВАНИЯ АРХЕОЛОГИЧЕСКИХ ОБЪЕКТОВ В ВЕРХОВЬЯХ РЕКИ ТУРГЕН (СеверНЫЙ Тянь-Шань)
}

\author{
(C) 2021 г. Болат Жагфарович Аубекеров ${ }^{31}$, \\ Саида Араповна Нигматова ${ }^{1,2}$ \\ ${ }^{1}$ доктор геолого-минералогических наук, \\ Институт геологических наук им. К. И. Сатпаева \\ ${ }^{1}$ доктор геолого-минералогических наук, \\ Институт геологических наук им. К. И. Сатпаева; \\ ${ }^{2}$ Институт археологии им. А. Х. Маргулана, г. Алматы, Казахстан. \\ E-mail: nigmatova@mail.ru
}

\begin{abstract}
Аннотация. В статье приведены данные по геоархеологическому изучению археологических объектов, расположенных в Северном Тянь-Шане - юго-западной части Жетысу в верховьях реки Турген. Археологические памятники расположены на поверхности останца морены. Они залегают друг над другом, образуя сложную многоярусную конструкцию. В зависимости от первоначального положения поверхности наблюдается смещение объектов от уступа останца к его середине и ближе к закраине. Геоархеологические исследования проводились в течение ряда лет, с 1999 по 2018 годы. В ходе работ были получены данные по геологии и геоморфологии региона, описаны гидрогеологические условия, изучена современная растительность этой территории, проведен палинологический анализ как отложений, включающих археологический объект (поселения), так и из естественных обнажений голоценового времени, обнажающихся в пойме реки Турген и ручья Кызылбулак.

Проведенные работы позволили значительно дополнить археологические представления информацией о палеосреде, в которой происходило освоение среднегорья Северного Тянь-Шаня. Кроме того, эти материалы были использованы для корреляции климатических событий, происходивших в пустынной и горной областях аридной зоны Центральной Азии в голоцене.
\end{abstract} гия, голоцен

Ключевые слова: археология, Турген, Кызылбулак, геоархеология, палиноло-

ТУРГЕН ӨЗЕНІНІН ЖОҒАРҒЫ АҒЫСЫНДАҒЫ АРХЕОЛОГИЯЛЫК НЫСАНДАРДЫ ГЕОАРХЕОЛОГИЯЛЫҚ ЗЕРТТЕУЛЕР (СоЛТүстік ТЯНЬ-Шань)

\author{
Болат Жағыфарұлы Аубекеров ${ }^{\mathrm{1}}$, Саида Араповна Нигматова ${ }^{1,2}$ \\ ${ }^{1}$ геолого-минералогия ғылымдарының докторы, \\ Қ. И. Сәтпаев атынд. Геологиялық ғылымдар институты \\ ${ }^{1}$ геолого-минералогия ғылымдарының докторы, \\ Қ. И. Сәтпаев атынд. Геологиялық ғылымдар институты; \\ ${ }^{2}$ Ә. Х. Марғұлан атынд. Археология институты, Алматы қ-сы, Қазақстан. \\ E-mail: nigmatova@mail.ru
}

\begin{abstract}
Аннотация. Мақалада Солтүстік Тянь-Шаньда - Жетісудың оңтүстікбатысындағы Түрген өзенінің жоғарғы ағысында орналасқан археологиялық нысандарды геоархеологиялық зерттеу мәліметтері берілген. Археологиялық
\end{abstract}

*Статья представляет собой расширенный вариант материалов, опубликованных в монографии А. А. Горячева [Аубекеров, Нигматова, 2020]. 
ескерткіштер мұз қозғалысынан пайда болған тау жыныстары сынықтарының үйіндісінің үстіне орналасқан. Олар бірінің үстіне бірі жатқан тау жыныстарының күрделі көпқабатты құрылымын құрайды. Үстіңгі қабаттың бастапқы жағдайына байланысты нысандардың қалдық таудың кемерінен ортасына және жиекке қарай алмасуы байқалады. Геоархеологиялық зерттеулер бірнеше жылдар қатарынан, 1999 жылдан 2018 жылдар аралығында жүргізілді. Жұмыс барысында аймақтың геологиялық және геоморфологиялық мәліметтері алынып, гидрогеологиялық жағдайы сипатталып, осы аумақтың қазіргі өсімдіктері зерттеліп, Түрген өзені мен Қызылбұлақ жылғасындағы археологиялық нысаны бар шөгінді, сондай-ақ голоцендік уақыт аралығында табиғи жолмен жалаңаштануына палинологиялық сараптама жасалынды. Жүргізілген жұмыстар Солтүстік Тянь-Шань ортатауларын игеру барысында жүрген палеоорта туралы археологиялық ақпаратты анағұрлым толықтыра түсуге мүмкіндік береді. Сонымен қатар, бұл материалдар голоцендегі Орталық Азияның аридтік зонасындағы шөл және таулы аймақтарындағы климаттық оқиғалардың корреляциясына пайдаланылды. голоцен

Түйін сөздер: археология, Түрген, Қызылбұлақ, геархеология, палинология,

\title{
GEOARCHAEOLOGICAL RESEARCH \\ OF ARCHAEOLOGICAL OBJECTS IN THE UPPER RIVER TURGEN (Northern Tien Shan)
}

\author{
Bolat Zh. Aubekerov ${ }^{\text {11, Saida A. Nigmatova }}{ }^{1,2}$ \\ ${ }^{1}$ Doctor of Geological and Mineralogical Sciences, \\ K. I. Satpayev Institute of Geological Sciences, \\ ${ }^{1}$ Doctor of Geological and Mineralogical Sciences, \\ K. I. Satpayev Institute of Geological Sciences, \\ ${ }^{2}$ A.Kh. Margulan Archeology Institute, Almaty, Kazakhstan. \\ E-mail:nigmatova@mail.ru
}

\begin{abstract}
The article provides data on the geoarchaeological study of archaeological sites located in the Northern Tien Shan (southwestern part of Jetysu) in the upper reaches of the Turgen River. Archaeological sites are located on the surface of the moraine outlier. They lie one above the other, forming a complex multi-tiered structure. Depending on the initial position of the surface, there is a displacement of objects from the outlier ledge to its middle and closer to the edge. Geoarchaeological research has been carried out for a number of years, from 1999 to 2018. In the course of the work, data on the geology and geomorphology of the region were obtained, hydrogeological conditions were described, the modern vegetation of this territory was studied, a palynological analysis was carried out both of sediments, including an archaeological site (settlements), and from natural outcrops of the Holocene time, exposed in the floodplain of the Turgen River and of the Kyzyl-Bulak stream. The work carried out made it possible to significantly supplement the archaeological concepts with information about the paleoenvironment in which the development of the middle mountains of the Northern Tien Shan took place. In addition, these materials were used to correlate climatic events that took place in the desert and mountainous regions of the arid zone of Central Asia in the Holocene.
\end{abstract}

Keywords: archaeology, Turgen river, Kyzylbulak stream, geoarchaeology, palynology, Holocene

\section{Введение}

Комплексный геоархеологический подход к изучению историкоархеологических памятников обусловлен пониманием того, что Человек является естественным звеном природной системы и находится в тесной зависимости от изменений природной ситуации (environmental archeology) и адаптации к ней.

В зависимости от использованных методов изучения археологического объекта и территории, на которой он расположен, появляются новые возможности получения корректной информации: 
Геоморфологические исследования позволяют получить сведения об особенностях рельефа, размещении археологических объектов и их связи с рельефом, изменения границ памятников, выявлении древних ирригационных систем и последовательности их создания и др. Геологические и геоморфологические исследования в некоторых случаях позволяют прогнозировать обнаружение новых памятников.

Гидрогеологические - необходимы на стадии первоначального изучения и понимания условий существования водных источников при изменении климата.

Ландиафтные, геоботанические, почвенные исследования - позволяют получить материалы по биопродуктивности района, почвенных и др. особенностях. Данные исследования имеют первостепенное значение на стадии обобщения материалов по археологическим комплексам, экологическим рекомендациям, при обосновании специализации охраняемых объектов - археологический памятник или ландшафтно-историкокультурный и т.д. Дают возможность говорить о лекарственных и кормовых растениях и в предположительной форме об их использовании в прошлом для культовых и лечебных целей.

Палеонтологические исследования - палеозоологические, палеокарпологические. Дают возможность получить сведения по составу животного и растительного мира прошлого.

Палинологические исследования - (палинология - это комплекс отраслей наук, связанных с изучением пыльцевых зёрен и спор) решают вопросы реконструкции растительного покрова и климата прошлых истори- ческих эпох, палеоэкологии человека от палеолита до современности, установления стратиграфических границ в археологических раскопах.

Палинологические данные дают возможность получить следующую информацию:

- сведения по смене растительного покрова с выделением информации о времени появления в разрезе культурных растений;

- стратиграфические границы в археологических раскопах, характер этих изменений;

- этапы изменения растительного покрова, связанные с изменениями как палеоклимата, так и под влиянием антропогенного фактора;

- направление климатических изменений на различных этапах существования археологического объекта и способствовать их относительному датированию;

- подтверждения влияния климата на становления различных типов хозяйства, на миграционные процессы и др.

\section{1 Геолого-геоморфологические} исследования на археологическом комплексе Турген-Кызылбулак

$$
\text { Жетысу/Семиречье - это слож- }
$$
ный природный комплекс, включающий высокогорья, вершины которых покрыты снеговыми шапками, обширные предгорные равнины, глубокие каньоны, песчаные пустыни, реку Иле и другие многочисленные реки и озеро Балхаш. Горные системы Жетысу образовались сравнительно недавно, в конце неогена и начале четвертичного периода, когда произошли крупноамплитудные тектонические движения по региональным разломам, глубоко проникающим в земную кору. По этим 
разломам крупные части пенеплена, в виде отдельных блоков, были подняты на разную высоту. Максимальные амплитуды обычно приходятся на осевые части хребтов.

Археологические объекты Кызылбулак-IV и Турген-II расположены в междуречье рек Турген и Асы в восточной части северного склона Иле/Заилийского Алатау. Высоко поднятый древний пенеплен в виде высокогорного плато сохранил достаточно большие площади в этих районах, занимая пространства по левобережью p. Чилик и простираясь почти до пика Талгар. Его поверхность наклонена на северо-восток.

\section{1 Физико-географическое по- ложение}

Река Турген образуется после слияния трех рек: слева - УлкенТурген, средней - Орта Турген и справа - реки Киши-Турген. Их истоки расположены на высоте 3000-4000 м и имеют ледниковое питание. В высокогорье и среднегорье река протекает по глубокому ущелью и отличается бурным течением. Общая длина реки от истока до устья 104 км, в горной части до с. Турген 43-45 км. Режим уровней воды в реке колеблется от 68 до 158 см, в отдельные годы наиболее высокий уровень достигал 240 см.

Река питается водами ледников, в бассейне реки имеется от 12 до 17 ледников.

Первые километры (около 10 км) река течет в восточном направлении по слабо наклоненному высокогорному плато, затем река постепенно углубляется в узком ущелье, северные склоны которого покрыты густым еловым лесом. После слияния с правым притоком Кайрак, стекающим с плато Ойкарагай, река повора- чивает на север и течет до слияния с рекой Шентурген. На притоке Кайрак находится Кайракский водопад, выше которого располагается красивое, поросшее островками елового леса, урочище Ойкарагай. До слияния с рекой Шентурген в реку Турген впадают шесть небольших притоков, стекающих с главного хребта Иле Алатау. После слияния с рекой Шентурген река Турген в урочище Батан сливается с рекой Киши Турген. Ниже урочища Батан в реку впадает еще четыре притока: по правому борту ущелья приток Карагайлы и ручей Медвежий, по левому борту - приток Терискенсу и ручей Микушин. Ниже Батана река течет в глубоком ущелье и впадает в Илейскую долину.

Река Асы протекает по северной части плато. На поверхности плато расположена высокогорная обсерватория. Рельеф представляет собой сложную по строению поверхность, образованную процессами денудации (пенеплен) и аккумуляции (моренный комплекс разного возраста, речные террасы и придолинные педименты).

\section{2 Геологическое строение} бассейна реки Турген достаточно сложное, что обусловлено широким развитием различных по составу и возрасту метаморфических, эффузивноосадочных и интрузивных формаций и интенсивными неоднократно проявившимися тектоническими движениями.

В верховьях реки Средний Турген развиты мощные отложения (1100-1300 м) нижнего протерозоя, представленные в основном амфиболитами, амфиболовыми, циозит-амфиболовыми и эпидотамфиболовыми сланцами.

Девонские образования осадочно-вулканогенной формации 


\section{ҚАЗАҚСТАН АРХЕОЛОГИЯСЫ № 1 (11) 2021}

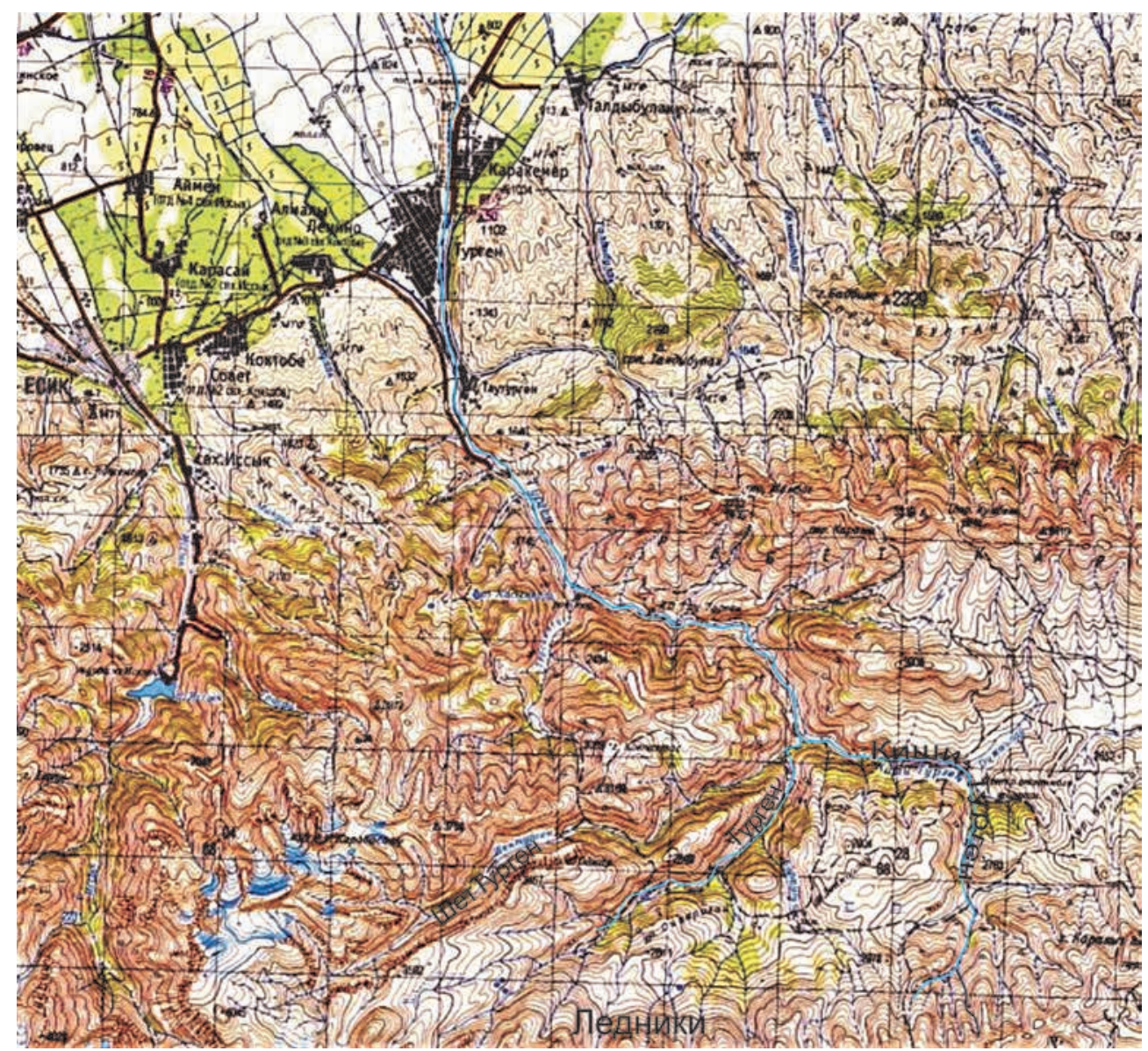

Рис. 1. Карта бассейна реки Турген

Fig. 1. Turgen River Basin Map

развиты в высокогорье по левому и правому склонам р. Улкен-Турген. Эти отложения представлены эффузивноосадочной формацией, в составе которой базальные конгломераты, песчаники аркозовые, конгломераты серые, порфириты и их туфы, туфоконгломераты, дацитовые порфиры, игнимбриты [Шлыгин, 1971, с. 27].

Отложения каменноугольной эпохи распространены в нижней части высокогорья и в среднегорье. К ким отнесены конгломераты, игним- бриты туфы, углистые сланцы. Последние встречаются в древних геологических отложениях и представляют уплотненную и измененную давлением и позднейшими метаморфическими процессами глину. В однородной массе его нередко встречаются включения колчедана, прожилки кварца и зерна известкового шпата [Шлыгин, 1971, c. 27].

Неогеновые отложения терригенной формации по возрасту отнесены к миоцену и плиоцену. 
Аубекеров Б.Ж., Нигматова С.А. Геоархеологические исследования археологических объектов ...

Миоцен обнаруживается на древних поверхностях выравнивания (2939-3700 абс. м) в верховьях бассейна. Эти отложения представлены кирпично-красными глинами санташской свиты, мергелями, с прослоями песчаников и конгломератов. Общая мощность 200-300 м.

Плиоцен (илийская свита) обнажается в верховьях реки КишиТурген и в уступах оползней - обвалов. При выходе рек из гор свита сложена палевыми щебнистыми глинами и суглинками с прослоями песчаников и конгломератов [Костенко, 1971, с. 45-60].

Четвертичные отложения отличаются неравномерным развитием по площади. Они имеют пестрый литологический состав и генезис. Здесь развиты гляциальные, флювиогляциальные, аллювиальные, аллювиальнопролювиальные, элювиально-делювиальные, делювиально-пролювиальные и др. отложения. По возрасту эти отложения могут быть расчленены на нижне-, средне-, верхнечетвертичные отложения и современные (голоценовые) [Костенко, 1971, с. 45-60; Бажанов, 1971, с. 503-515].

Нижнечетвертичные отложения формируют мощные морены первого полупокровного оледенения, состоящие из слабоокатанных глыб пород допалеозоя и палеозоя, заполнитель песчано-дресвяно суглинистый. Мощность морен до 150 м. [Костенко, 1978, с. 35-78]

К нижнечетвертичным отнесены флювиогляциальные эоловые осадки предгорий (прилавки). Нижняя часть прилавков сложена валунногалечниками мощностью 100-150 м.

Вверху залегают лессовидные суглинки, лессы эолового происхождения.
Морены среднечетвертичного возраста развиты в бассейне очень слабо. Они отмечаются в нижней части высокогорий.

Верхнечетвертичные и современные отложения представлены ледниковыми аллювиальнопролювиальными, аллювиальными и элювиально-делювиальными образованиями.

Ледниковые накопления развиты в верховьях всех крупных притоков реки Турген. Состоят они из несортированного обломочного материала. Поверхность верхнечетвертичных морен задернована, волнистая, с развалами валунов и глыб, мощностью отложений до 150 м.

Аллювиальные и аллювиальнопролювиальные отложения слагают обычно террасы рек мощностью от 5 до 15 м. При выходе из гор они формируют конусы выноса, сливающиеся в предгорный шлейф.

Аллювиально-делювиальные нерасчлененные осадки широко распространены в горной части на водоразделах и прилегающих склонах речных долин. Мощность невелика от 1,5 до $3 \mathrm{м}$.

Значительная часть бассейна реки Турген, особенно в верховьях и большая часть хребта Караш сложены интрузивными палеозойскими образованиями кембрия, ордовика, карбона и перми (составлено Б. Ж. Аубекеровым в 1999 г. - по материалам полевых дневников).

1.3 Геоморфология района исследования (составлено Б. Ж. Аубекеровым)

На площади бассейна в результате перемещения блоков земной коры под воздействием тектонических сил и денудации ее поверхности созда- 
ны два основных комплекса рельефа: горный и предгорный.

Горный включает в себя альпинотипный, древнеледниковый интенсивно-расчлененный и древнеледниковый умеренно-расчлененный типы рельефа.

Альпинотипный рельеф развит в приводораздельной части хребта на высоте более 3500 м. Рельеф отличается узкими скалистыми гребнями водоразделов, крутыми, часто отвесными склонами с наличием действующих цирков, каров, троговых долин, подвижных осыпей, снежников, фирновых полей, ледников.

Древнеледниковый интенсивнорасчлененный рельеф распространен гипсометрически ниже альпинотипного. Здесь троговые долины широкие, с крутыми склонами 40-70 и узкими скалистыми водораздельными гребнями, превышение которых достигает 1000 м. Современные ледники отсутствуют.

Древнеледниковый умереннорасчлененный рельеф развит в верховьях бассейна, от предыдущего типа отличается меньшей расчлененностью и меньшими относительными превышениями до 500 м и более пологими склонами троговых долин и сглаженными водоразделами. входит:

В горный комплекс также

a) эрозионный интенсивнорасчлененный тип рельефа высоких гор на абсолютных отметках более 2500 м;

б) эрозионный умереннорасчленённый тип рельефа более низких гор на высотах от 1800 до 2500 м.

Рельеф наклонной доолигоценовой денудационной поверхности, расчлененный современными речными долинами, наблюдается в верховьях бассейна реки Турген. Это достаточно ровные, слегка наклонные поверхности (урочища Донжайлау, Картогул, Ойжайлау, Ойкарагай) в северном направлении, выработанные на дислоцированных породах палеозоя и перекрытых неогеновыми осадками.

В интервале отметок 11001600 м расположена верхняя предгорная ступень (в бассейне нижняя ступень отсутствует), отделенная от предгорного аллювиальнопролювиального шлейфа тектоническим уступом высотой до 200 м. Морфологическая ступень относится к низкогорью с мягкими плавными очертаниями.

Предгорный тип рельефа расположен в интервале 600-1100 м. Он образован в результате слияния конусов выноса горных рек и чётко выражен в рельефе с уклоном поверхности около $10^{\circ}-12^{\circ}$. Ширина образованного шлейфа достигает 20 км (составлено Б. Ж. Аубекеровым в 1999 г.).

\section{4 Подземные воды}

В гидрогеологическом отношении бассейн реки Турген, как и весь северный склон Иле Алатау, приурочен к южной части крупного илийского артезианского бассейна. Здесь могут быть выделены два основных типа подземных вод: трещинные воды палеозойского фундамента и поровые воды неоген четвертичных отложений.

Трещзинные воды палеозойского фундамента горной части связаны главным образом с гранитоидами и эффузивами. Скальные породы характеризуются сравнительно благоприятными гидрогеологическими условиями.

Верхняя зона скальных массивов интенсивно раздроблена трещи- 
Аубекеров Б.Ж., Нигматова С.А. Геоархеологические исследования археологических объектов ...

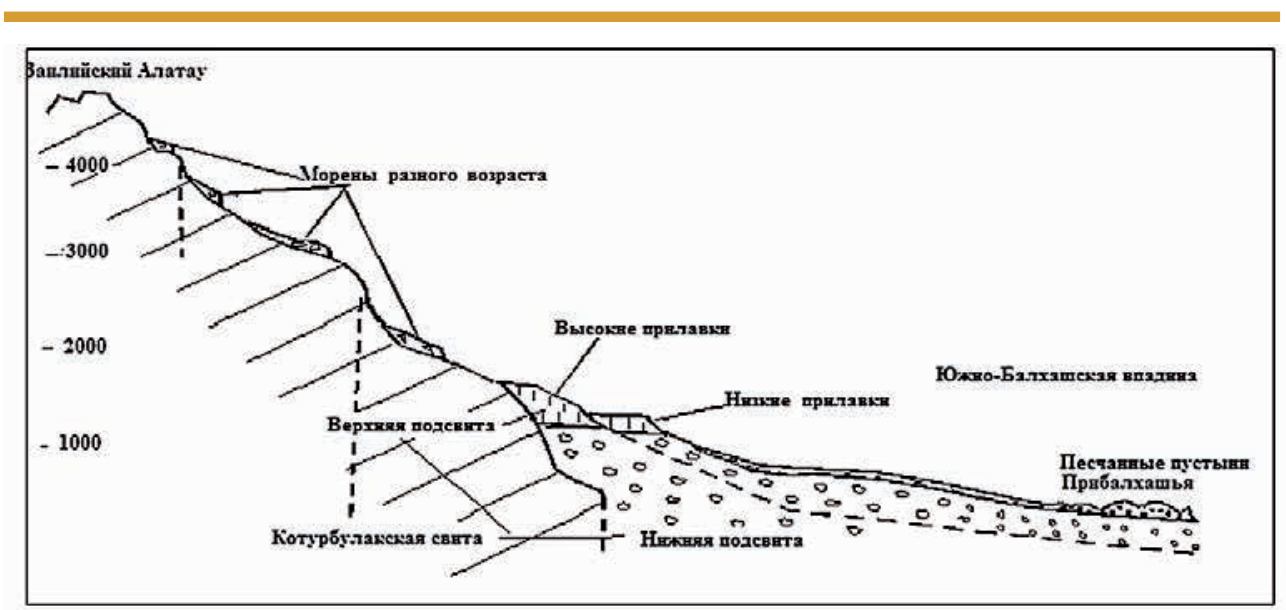

Рис. 2. Геолого-геоморфологический профиль

через северные склоны Иле Алатау до Южно-Балхашской впадинь

Fig. 2. Geological and geomorphological profile

through the northern slopes of the Ile Alatau to the South Balkhash depression
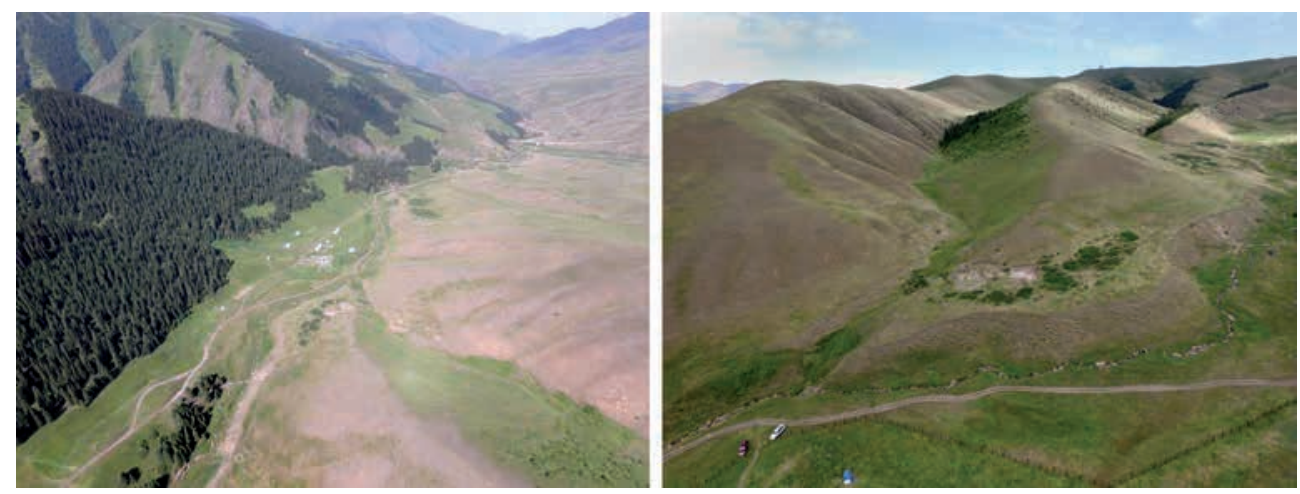

Рис. 3. Общий вид на долину реки Турген и археологические объекты

Fig. 3. General view of the Turgen river valley and archaeological sites

нами выветривания, а климатические условия благоприятствуют формированию значительных запасов подземных вод. Площадь распространения трещинных вод обычно совпадает с областью питания, в основном обусловлена поглощением поверхностного стока. Трещинноватость скальных пород в горизонтальном направлении относительно равномерна, в вертикальном разрезе наблюдается постепенное затухание трещин с глубиной.
Поэтому распределение естественных ресурсов подземных вод на площади бассейна также равномерно.

Воды трещин выветривания имеют свободный водообмен с поверхностью и приурочены к хорошо промытым породам. Поэтому они обладают хорошими качествами и слабой минерализацией (до 0,5 г/л). В долинах бассейна фиксируются многочисленные родники с дебетом от десятых долей до 5 л/с и более. 


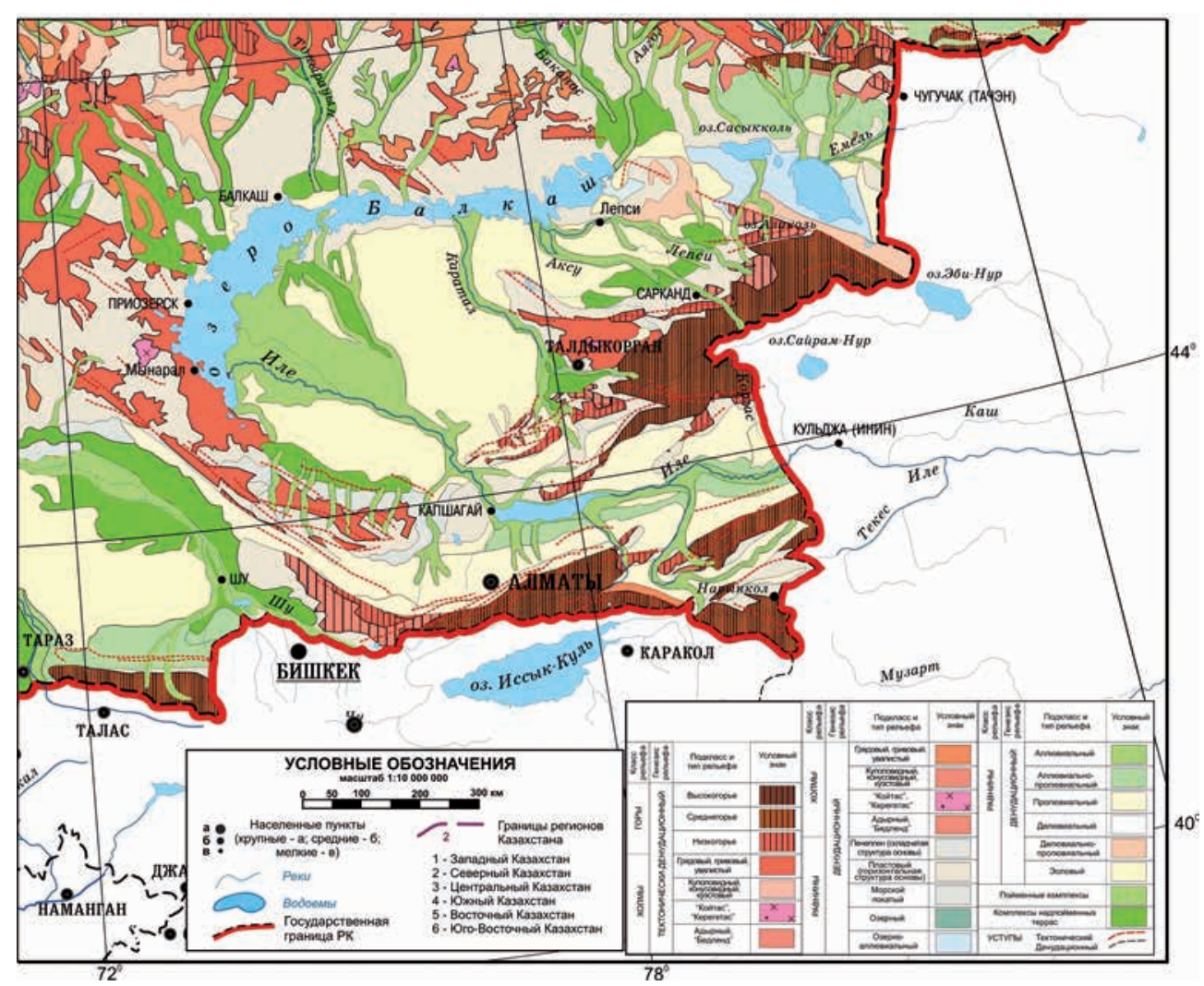

Рис. 4. Природные ландмафты и геоморфологическое строение Жетысу

Fig. 4. Natural landscapes and geomorphological structure of Jetysu

Разгрузка подземных вод наблюдается, как правило, у основания склонов и в долинах рек.

Воды тектонических трещин обычно связаны с зоной региональных нарушений.

Поровые пластовые воды приурочены к рыхлым и слабосцементированным породам неогенчетвертичных отложений, заполняя в них крупные пустоты и поры. В верховьях бассейна на поверхности выравнивания воды выклиниваются, образуя заболоченности.

Воды четвертичных отложений значительное распространение получили в ледниковых аллювиальные и аллювиально-пролювиальных от- ложениях. Наибольшее развитие они имеют в моренах за счет таяниям ледников.

В уступах верхнечетвертичных и современных морен фиксируются выходы родников, дебеты которых достигают 15 л/с и более.

Воды аллювиальных и аллювиально-пролювиальных отложений развиты по всем речным долинам бассейна. Водообильность отложений в зависимости от литологического состава может значительно колебаться.

\section{5 Расположение археологиче-} ских объектов

Долина р. Кызылбулак имеет сложное строение. Первоначально это 
Аубекеров Б.Ж., Нигматова С.А. Геоархеологические исследования археологических объектов ...

была ледниковая долина-трог, позже использованная эрозионной долиной. Здесь наблюдаются два уровня морен и 2-3 речные террасы.

Ложем для долины в верхней части служат неогеновые глины (красноцветы санташской свиты). Ниже по течению долина прорезает моренные отложения и врезается в палеозойские породы.

Ледниковые и речные отложения сохранились в виде фрагментов по обоим бортам долины.

Северная часть плато сильно расчленена долиной р. Турген и ее притоками. Многочисленные поселения расположены в долине одного из притоков р. Кызылбулак на морене позднего плейстоцена, сохранившейся на правом борту долины. Моренные отложения, как правило, сложены неслоистыми несортированными толщами из материала различного размера обломков, от глыб до тонкого глинистого материала. В горных моренах преобладает щебень и глыбы с песчано-глинистым заполнителем. От склоновых отложений морены отличаются присутствием обломков чуждых горных пород (здесь и далее составлено Б. Ж. Аубекеровым в 1999 г.).
Фрагмент морены имеет длину около 700 м, и его площадка возвышается над урезом воды в реке на 25 м. Ширина площадки колеблется от 30 до 150 м, имеет наклон в сторону русла и вниз по течению. Ее закраина маскируется делювиальным чехлом, сложенным супесями и суглинками с включениями щебенки. Скорость накопления делювия значительная, о чем свидетельствуют данные раскопа (рук. А. А. Горячев, Институт археологии им. А. Х. Маргулана, см. подробнее: [Горячев, 2020]) - поселения эпохи поздней бронзы находятся в погребенном состоянии на глубине более 2 м у подножья сопки.

Вся поверхность останца морены занята археологическими объектами. Они залегают друг над другом, образуя сложную многоярусную конструкцию. В зависимости от первоначального положения поверхности наблюдается смещение объектов от уступа останца к его середине и ближе к закраине.

В геологическом строении останца принимают участие снизувверх валунно-галечниковые отложения мощностью более 15 м с суглинистым заполнителем, перекрытые

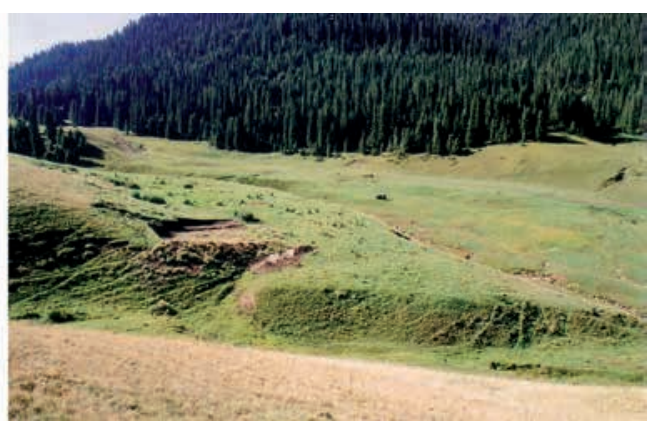

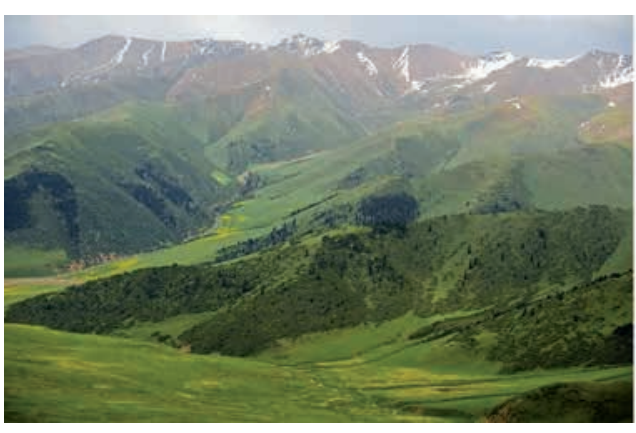

Рис. 5. Долина реки Турген

Fig. 5. Valley of the Turgen River 
сверху делювием со склонов горы. Мощность делювиального чехла у подножья склона достигает до 1,5 м и уменьшается до 0,5 м у бровки останца морены.

Вниз по течению площадка ограничена поперечной небольшой долиной, которая срезает этот останец. Площадка морены является наиболее удобной для освоения, что и обусловило ее заселение в течение длительного времени. Выбор отложений морены был, по-видимому, не случаен: морена выполнена суглинистыми рыхлыми отложениями, насыщена водой и лишена древесной растительности.

Свидетельством длительности заселения этого участка является большое количество культурных слоев, вскрытых при археологических раскопках. Они залегают друг над другом, образуя сложнопостроенный многослойный культурный слой.

Более ранние объекты относятся к эпохе бронзы, от поселения этого времени остался пол и остатки конструкций, которые располагаются ближе к склону горы, а более поздние объекты - ближе к бровке, что было связано, по-видимому, с постепенным накоплением у закраины делювиального чехла.

Разрез на поселении эпохи бронзы от которого остался пол с сохранившимися элементами жилища, был врезан в присклоновую часть и после того как его покинули, постепенно был перекрыт делювием со склона горы.

Разрез здесь следующий (по: Б. Ж. Аубекерову, полевые дневники 1999 г.):

1. Супесь светло-коричневая, с включением мелкой гальки - 0,15 м.

2. Зольный слой $-0,15$ м.
3. Ниже залегают супеси и суглинки до глубины 2 м, в нижней части которых на глубине 1,6 м вскрыт пол, хорошо различимый в разрезе по сильной карбонатизации суглинков и их большой плотности. Выделяются два уровня пола, залегающие друг над другом. По образцам, отобранным Б. Ж. Аубекеровым и А. А. Горячевым, получена ЭПР дата, имеющая возраст 3300 лет (С. П. Пивоваров Институт ядерной физики, 2001 - из полевых дневников Б. Ж. Аубекерова). По данным А. А. Горячева, собранные артефакты свидетельствуют о существовании поселения в эпоху поздней бронзы. Супеси и суглинки имеют включения гравия и обломки местных пород $-2 \mathrm{м}$.

5. Основание жилища-верхняя часть моренных отложений. Вскрытая часть составила около 0,4 м.

Разрез отложений на останце, расположенном ближе к бровке, существенно отличается от описанного. Это связано с достаточно длительным временем, прошедшем после того, как было покинуто жилище эпохи бронзы. За это время успел сформироваться достаточно мощный делювиальный покров и почвенно-растительный слой, на котором расположилось поселение раннего железного века.

Ниже приводится разрез стенки раскопа Турген II (по полевым дневникам Б. Ж. Аубекерова, 1999 г.), расположенный в центральной его части (раскоп 1999-2001 гг., рук. А. А. Горячев):

Слой 1 - современная горнолуговая почва с кротовинами, темносерого цвета. В ней сохранились фрагменты конструкций- 0,3-0,4 м.

Слой 2 - подпочвенный слой светлосерого цвета с включениями 
Аубекеров Б.Ж., Нигматова С.А. Геоархеологические исследования археологических объектов ...

песка, щебенки и гравия, иногда дресвы и гальки - 0,1 м.

Слой 3 -красновато-коричневый слой, сложенный суглинками с включениями обломков пород в виде дресвы. В слое наблюдаются кротовины и в нем в виде линзы расположен слой $4-0,3$ м.

Слой 4 - слой красной супеси (по данным археологов - пол) - 0,1$0,15 \mathrm{M}$.

Слой 5 - черный суглинок один из слоев пола.
Слой 6 - светло-серая рыхлая супесь элемент пола. В слоях 3-6 зафиксированы остатки жилищ раннего железного века, в которых отмечено присутствие керамики сакского времени (по мнению А. А. Горячева).

Слой 7 - слой почти черного цвета. Ископаемый почвеннорастительный слой, суглинистый, плотный, с большим количеством кротовин (заполнены обычно легкими супесями или суглинками). В слое много включений щебенки и дресвы.

Слой 1 Современная луговая почва с кротовинами, темно-серого цвета. В ней сохранились фрагменты конструкций 0.3-0.4M

Слой 2 Подпочвенный слой светло серого цвета с включениями песка, щебенки и гравия, иногда дресьвы и гальки. $-0.1 \mathrm{~m}$

Слой 3 Красновато-коричневый слой сложенный суглинками с включениями обломков пород в виде дресьвы. В слое наблюдаются кротовины -

$0.3 \mathrm{M}$

Слой 4 Светло-серая рыхлая супесь

Слой 5 темно-серого, почти черного цвета. Вероятно это древняя почва, суглинистая, плотная, с большим количеством кротовин (заполнены обычно легкими супесями или суглинками. В слое достаточно много включений щебенки и дресьвы.

Слой 6 Суглинистый щебенистый слой с неровной кровлей и подошвой, коричневогоцвета, влажный, скротовинами.

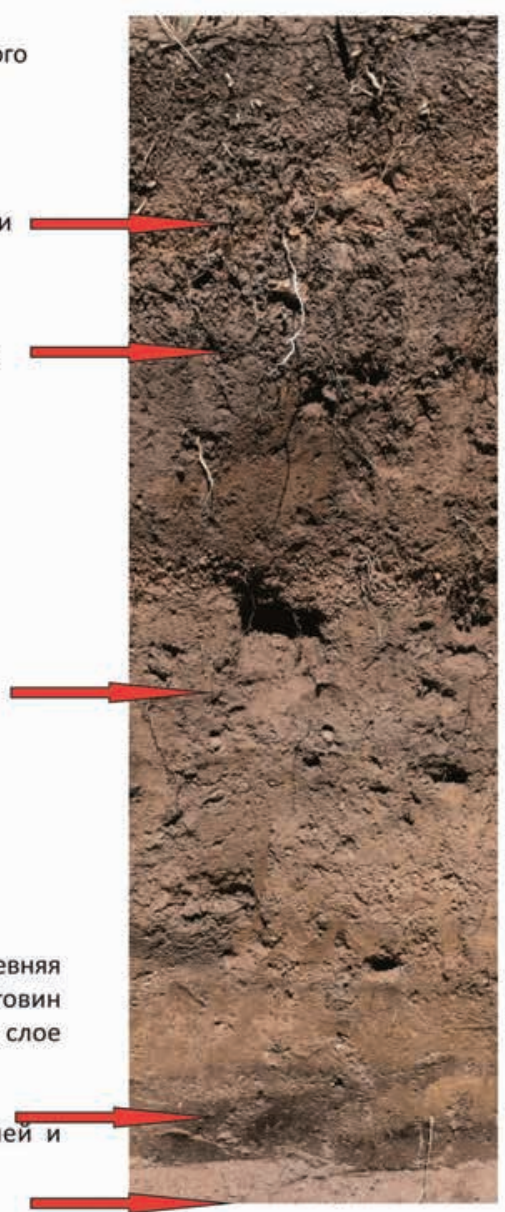

Рис. 6. Разрез стенки раскопа Кызылбулак-IV

Fig. 6. Section of the wall of the Kyzylbulak-IV excavation site 

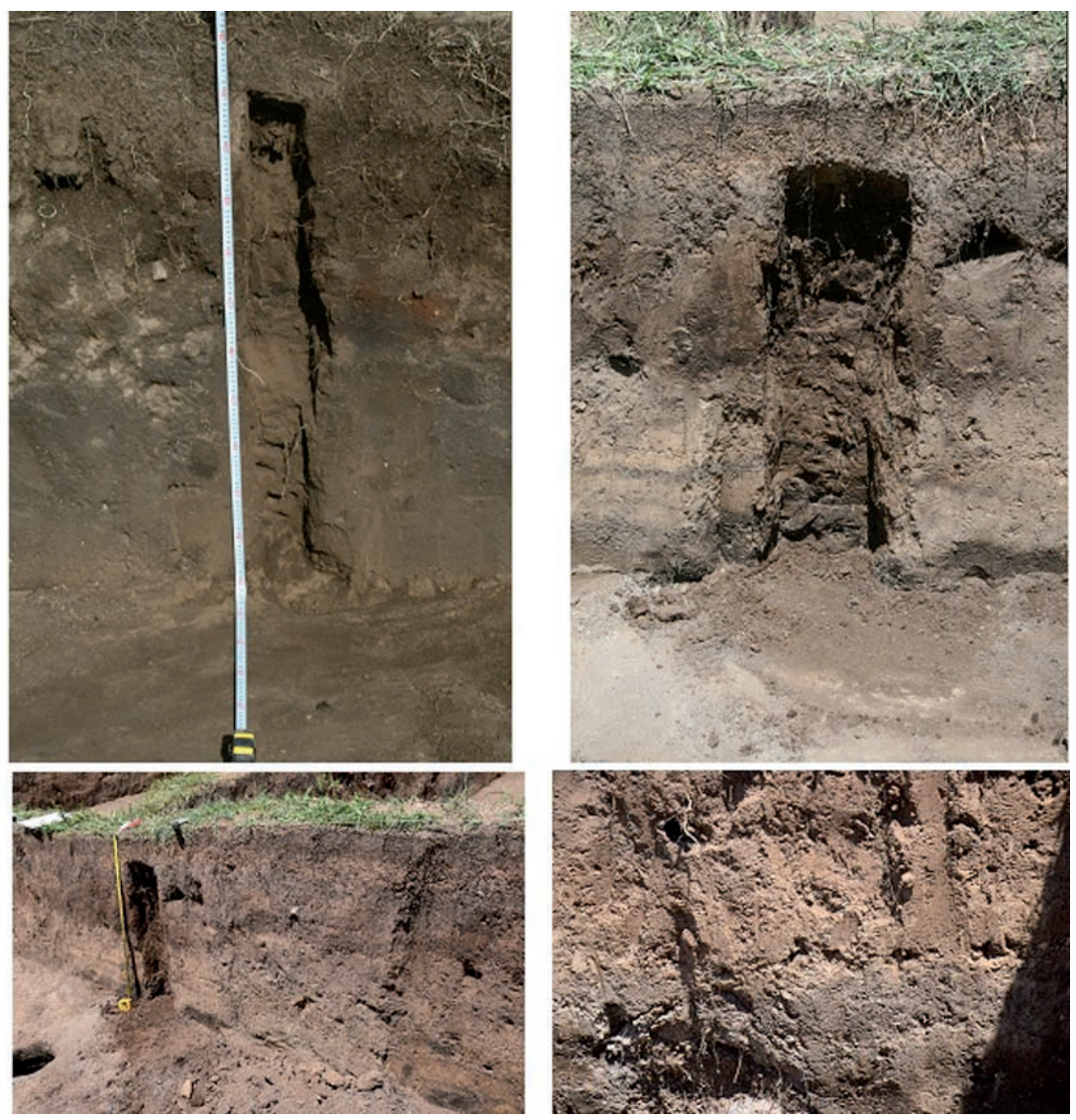

Рис. 7. Разрез бровки поселения Кызылбулак-IV

Fig. 7. Side section of the Kyzylbulak-IV settlement

Границы слоя (кровля и подошва не ровные имеют следы размыва или срезания). Именно на этом слое залегает многослойный цветной пол (слои 4-6).

Слой 8 - суглинистый щебенистый слой с неровной кровлей и подошвой, коричневого цвета, влажный, с кротовинами. В слоях 7 и 8 собраны фрагменты керамики раннего железного века и бронзового века (по мнению А. А. Горячева и А. С. Ермолаевой, Институт археологии им. А. Х. Маргулана, они являются местными аналогами керамики донгальского и валиковского типов).

Слой 9 - песок разнозернистый с примесью щебенки и гальки - моренный материал.
Общая глубина раскопа на этом участке около 2,5 м.

На противоположной стороне обнаружена выровненная площадка, расположенная в лесной зоне, но лишенная древесной растительности. На дневной поверхности слабо различимы фрагменты конструкций и найдены куски шлаков, которые были переданы в Институт геологических наук им. К. И. Сатпаева на спектральный анализ.

Результат анализа показал, что это шлаки, получаемые при сыродутном способе получения железа. Вкрапления металлического железа нередко содержатся в базальтовых и других изверженных породах. 
Аубекеров Б.Ж., Нигматова С.А. Геоархеологические исследования археологических объектов ...

Наиболее распространенные железные руды представляют собой соединения железа с кислородом (оксид железа), или гидрат окиси железа. Для выделения металлического железа из этих соединений необходимо провести его восстановление.

Как известно, температура плавления железа составляет $1539^{\circ} \mathrm{C}$, получить такую температуру достаточно сложно. Но древние металлурги обнаружили, что металлическое железо можно получать и при гораздо меньших температурах, но при этом должно быть больше топлива, чем при выплавке меди, и это топливо должно быть лучшего качества. Необходимо также, чтобы огонь был как можно более «горячим». Все это требовало особого устройства печи и условий плавки. Вероятно, именно поэтому окалины найдены в зоне леса, где была возможность получать древесный уголь в больших количествах.

2 Палинологическое изучение поселений Турген-II и Кызылбулак-IV

Целью проведения споровопыльцевого анализа (палинологического) образцов из археологических объектов Турген-Кызылбулак является относительное датирование, реконструкция палеоклиматической и палеоландшафтной обстановок, выявление особенностей растительности близ поселения.

Палинологический анализ (метод), основан на изучении пыльцы и спор растений из отложений, включающих культурные слои различных эпох, и является в настоящее время неотъемлемой частью археологических исследований. Споры и пыльца рассеиваются с помощью ветра, воды, животных и покрывают дневную поверхность суши и воды, сохраняясь в осадочных отложениях миллионы лет. Таким образом, практически все осадочные отложения содержат в разном количестве фоссилизированные споры и пыльцу, из которых и складывается спорово-пыльцевой спектр $\left(\mathrm{CПC,} \mathrm{палиноспектр}{ }^{1}\right)$ каждого горизонта.

Благодаря высокопрочной оболочке споры и пыльца сохраняются миллионы лет в осадочных отложениях и могут быть выделены из породы в лабораторных условиях, путем растворения в кислотах и вымывания гумидных кислот и солей, центрифугирования в тяжелой жидкости. Идентификация пыльцевых зерен и спор проводится под микроскопом и основана на работах Л. А. Куприяновой [Куприянова, 1965, с. 7-216; Куприянова, Алешина, 1972, с. 5-172; 1978, c. 5-182;], М. Х. Монозсон [Монозсон, 1959, с. 178-198], Л. Н. Чупиной [Чупина, 1978, с. 58-63], а также на изучении коллекции постоянных препаратов пыльцы современных растений.

Палинологический метод является практически единственным палеонтологическим методом, позволяющим расчленять невыразительные толщи голоценовых (от 11000 лет назад) отложений в аридной зоне и определять климатостратиграфические горизонты [Нигматова, 2008, c. 4-15].

\section{1 Современная раститель-} Hость

Согласно карте растительности 2003 г. [Рачковская и др., 2003, с. 424], все подгорные равнины, окаймляю-

${ }^{1}$ Палиноспектр - совокупность и процентное соотношение пыльцы и спор, выделенных из одного образца. 
щие хребты Северного Тянь-Шаня (к востоку от северо-восточного склона Сырдарьинского Каратау) и Джунгарского/Жетысу Алатау, отнесены к Присеверотяньшаньской предгорной подпровинции ДжунгароСеверотяньшанской провинции [Волкова, 2003, с. 217-219]. Для подпровинции характерны полукустарничковые и кустарниковые пустыни с эфемероидами, сменяющиеся при приближении к горам, остепненными пустынями с участием злаков и эфемероидов.

Заилийская горная подпровинция охватывает хребет Иле Алатау. В сухих и опустыненных степях низко- горного яруса наблюдается значительная роль эфемероидов.

В Северном Тянь-Шане кустарниковые заросли очень характерны для степного пояса и представлены они, в основном, розариями. Основными доминантами являются розы (Rosa plathyacantha, R. pimpinelifolia), спирея (Spiraea lasiocarpa) и виды кизильников (Cotoneaster melanocarpus, C. multiflorus, C. polyanthemus).

Древесная растительность в Северном Тянь-Шане располагается преимущественно на склонах северных экспозиций. У основания гор произрастают различные кустарники, на высоте 1000-1200 м они сменяют-

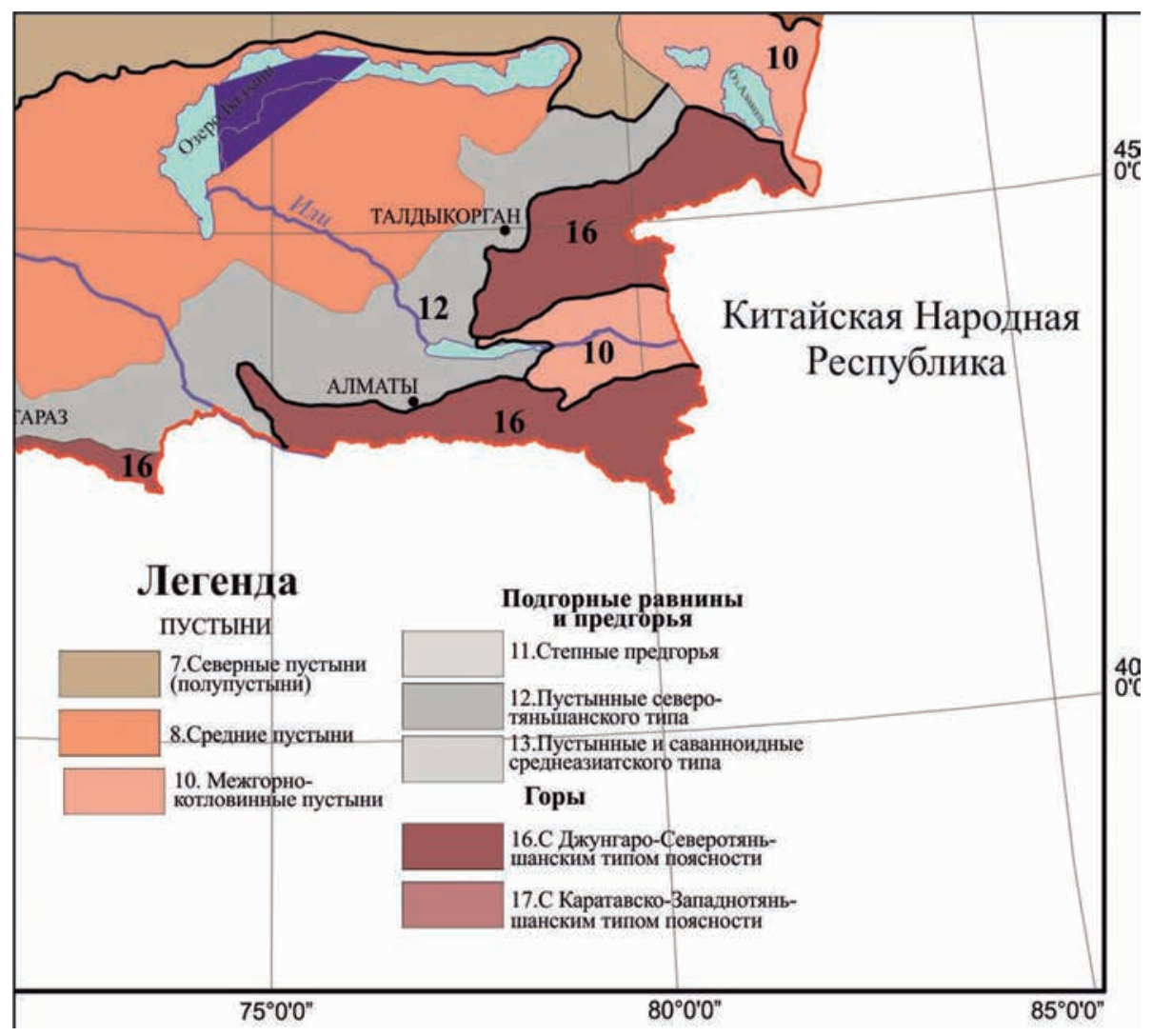

Рис. 8. Фрагмент карты растительности Юго-Восточной части Казахстана (по: [Рачковская и др., 2003])

Fig. 8. Fragment of the vegetation map of the Southeastern part of Kazakhstan (after: [Rachkovskaya et al., 2003]) 
Аубекеров Б.Ж., Нигматова С.А. Геоархеологические исследования археологических объектов ...

ся лиственными лесами. На высоте 1300 м к лиственным примешивается ель тяньшанская, а с 1500 и до 2800 м произрастают чистые еловые насаждения. Выше этой зоны ель сменяется стланиковыми можжевельниками.

Лиственные леса из яблони, абрикоса, осины образуют светлые насаждения на горных склонах $\mathrm{Ce}$ верного Тянь-Шаня. Под их редким пологом развит густой кустарниковый ярус из боярки, ирги, барбариса. Травяной покров также богатый. В нем обычны такие крупные злаки, как Melica altissima, Dactylis glomerata и многие виды крупного разнотравья.

Выше они сменяются хвойными монодоминантными лесами из ели тяньшанской Picea schrenkiana. В высокогорьях преобладают среднетравные и низкотравные луга.

В нижней части хвойного леса встречается примесь лиственных пород - березы (Betula tianschanica), осины (Populus tremula), тяньшанской рябины (Sorbus tianschanica). Леса эти имеют часто парковый характер: деревья не образуют сплошного по- лога, а распределены более или менее обособленными группами.

На более пологих склонах с развитым почвенным покровом обычны кустарники (Rosa alberti, Rubus idaeus, Ribes meyeri виды р. Lonicera и другие). В промежутках между группами деревьев, при достаточном почвенном покрове, развивается густой травостой. На крутых склонах северных экспозиций и в днищах ущелий встречаются участки густых моховых ельников с таежными элементами в травяном ярусе (Goodyera repens, Arctous alpina).

Выше лесного пояса в Северном Тянь-Шане расположены среднетравные манжетковые луга (Alchemilla retropilosa, A. sibirica, Hedysarum neglectum, Trollius dschungaricus), которые встречаются в сочетании со стланиковой арчой (Juniperus pseudosabina). Кроме того, для Иле Алатау характерны также фломисовые (Phlomoides oreophylla) и гераниевые луга (Geranium saxatile, G. collinum, G. albiflorum).

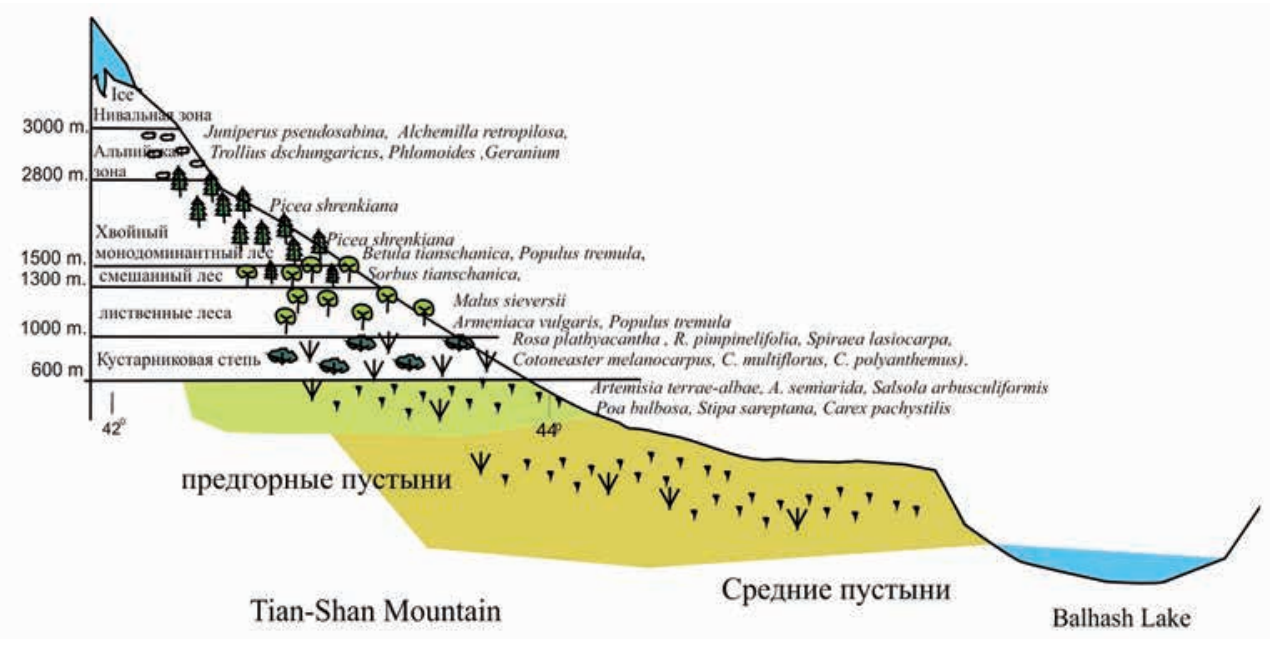

Рис. 9. Схема распределения растительности по вертикальным поясам Северного Тянь-Шаня

Fig. 9. Vegetation distribution scheme along the vertical belts of the Northern Tien Shan 
2.2 Палинологическое изучение

Палинологическое изучение отложений поселения Турген-II и Кызылбулак-IV было начато еще в 1999 г. в рамках международного гранта ИНТАС 97-2220 «Процесс формирования кочевых обществ в Семиречье эпохи бронзы и раннего железа. Экология и археология» по обширному семиреченскому региону Южного Казахстана комплексной геолого-археологическойэкспедицией совместно с геологами Б. Ж. Аубекеровым и палеоклиматологами Р. Сала, Ж. М. Деом, почвоведом Ю. Г. Евстифеевым и др. [Аубекеров и др., 2001, с. 26-34]. В 2018 г. палинологическое изучение было продолжено и отобраны образцы из археологических объектов Кызылбулак-IV.

Наиболее полный разрез поселения был вскрыт на объектах ТургенII (эпоха бронзы) и Турген-I (ранний железный век).

Из поселения бронзового века Турген-ІІ было отобрано на споровопыльцевой анализ (СПА) 16 образцов. Глубина пробоотбора составила 2 м.

Для палинокомплекса ТургенII характерно заметное участие древесно-кустарниковых форм (до $28 \%$ ). В их составе отмечены пыльцевые зерна Picea sp, Ephedra sp, Betula sp, Salix sp. Пыльца травянистых растений составляет от 72 до $80 \%$ и играет доминирующую роль в спектрах. В ее составе установлены следующие семейства и роды - Chenopodiaceae sp., Ranunculaceae sp., Geraniacea sp., Valeriniacea sp., Asteraceae sp. (Artemisia sp., Sonchus sp., Cirsium sp., Taraxacum и др.), Poaceae(Poa pratense) и др.

Кроме того, установлены в спектрах и споры папоротников и мхов. Однако СП сохранились не во всех образцах. В некоторых препаратах практически не обнаружено органических остатков (с глубин 2,0 до 1,5 м). В пробах 8-11 (гл. 0,8-0,65 м) очень большое содержание обуглившейся органики. В образцах с глубины 0,65-0,35 м растительные остатки представлены водорослями, грибами и цистами грибов.

По изменениям в составе СПК нам удалось выделить несколько экологических микрозон, характеризующихся изменениями температуры и влагообеспеченности, что, в свою очередь, ведет к изменениям в палиноспектрах.

Первый (современный) этап, глубина пробоотбора 0,1 м. Представлена пыльца древесных (20,5\%) и травянистых мезофильных растений, произрастающих вдоль берегов ручьев и горных речек.

Второй этап (гл. 0,3 м) близок по составу к современному, однако, здесь несколько выше содержание пыльцы древесных растений (24,8\%), травянистые формы представлены большим числом семейств и родов это позволяет считать климат этого этапа несколько более теплым и влажным чем современный.

Третий этап (гл. 0,35-0,55 м) характеризуется малым числом пыльцевых зерен и спор. Установлены только единичные зерна Picea sp. и Chenopodiaceae sp., а также в большом количестве цисты грибов, водорослей и водорослеподобные формы, что свидетельствует о большой влажности климата

Шестой этап (0,65-0,8 м). Выделен по общему признаку - во всех четырех пробах встречены только обугленные растительные остатки (СП, водорослей, грибов не установлено).

Седьмой этап (гл. 0,9 м). Пыльцевых зерен мало, пыльца древесных 
растений не установлена, состав травянистых крайне обеднен. Здесь установлена спора Selaginella, что, повидимому, может указывать на влажность. В целом, климат был влажный и холодный.

Восьмой этап (гл. 1,10 м) Характеризуется полным отсутствием растительных остатков.

Девятый этап (гл. 1,25 м). Пыльца древесных растений достигает 8\%, травы представлены небольшим числом родов и семейств, в основном, это представители семейства Chenopodiacae sp., Asteraceae (Artemisia sp., Sonhus sp.). Климат относительно благоприятный для жизни и вероятно о хозяйственной деятельности и уничтожении естественного растительного покрова свидетельствует появление в спектрах осота (Sonchus sp.), сорного растения: сопровождающего человеческие поселения, мусорные места и др. (за исключением S. palustris).

На десятом этапе (гл. 1,301,50 м) наблюдается повышение температуры и влагообеспеченности (приближен к современному). Увеличивается процент пыльцы древесных форм, увеличивается число семейств и родов травянистых растений в палиноспектре.

По результатам изучения данных отложений (поселение Турген-II) достаточно сложно судить о происходивших изменениях климата, так как на формировании этих СПК отразились следы хозяйственной деятельности человека и особенности его быта: очищение места поселения от естественной (фоновой) для данной территории растительности, выжигание или посыпание горячей золой почвы (на что указывают многочисленные обугленные органические частицы в пробах). Однако можно с уверенностью говорить об относительной длительности существования самого поселения и об антропогенном влиянии на изменение растительности в это время.

В целом, состав СПК свидетельствует о существовании достаточно мезофильной растительности вокруг поселения, в непосредственной близости с лесными формациями.

В палинокомплексе Турген-I ведущая роль принадлежит пыльце травянистых растений - полыни (Artemisia sp.), представителям семейств Asteraceae, Chenopodiaceae, Poaceae. Пыльца растений других систематических групп представлена незначительно.

Пыльца древесных растений (в основном, ели) составляет от 4 до $18 \%$. В группе древесных форм доминирует пыльца хвойных (Piceae sp.), другие древесные представлены единичными пыльцевыми зернами. Кроме того, в палинокомплексе были установлены споры папоротников и почвенных грибов. Таксономический и количественный состав палиноспектров заметно изменяется по разрезу. Так, в пробах близких к поверхности $(0,1-0,4$ м), состав спорово-пыльцевого спектра аналогичен составу современной растительности, существующей в данном районе.

В образцах с глубины 0,65 м выделен палиноспектр, в котором пыльце древесных принадлежит 18\%, что свидетельствует о расширении зоны леса. Травянистые растения также представлены большим числом видов. Всё это указывает на достаточно влажный и умеренный климат, благоприятствующий развитию елового леса с богатым подлеском и травостоем на безлесных участках. 


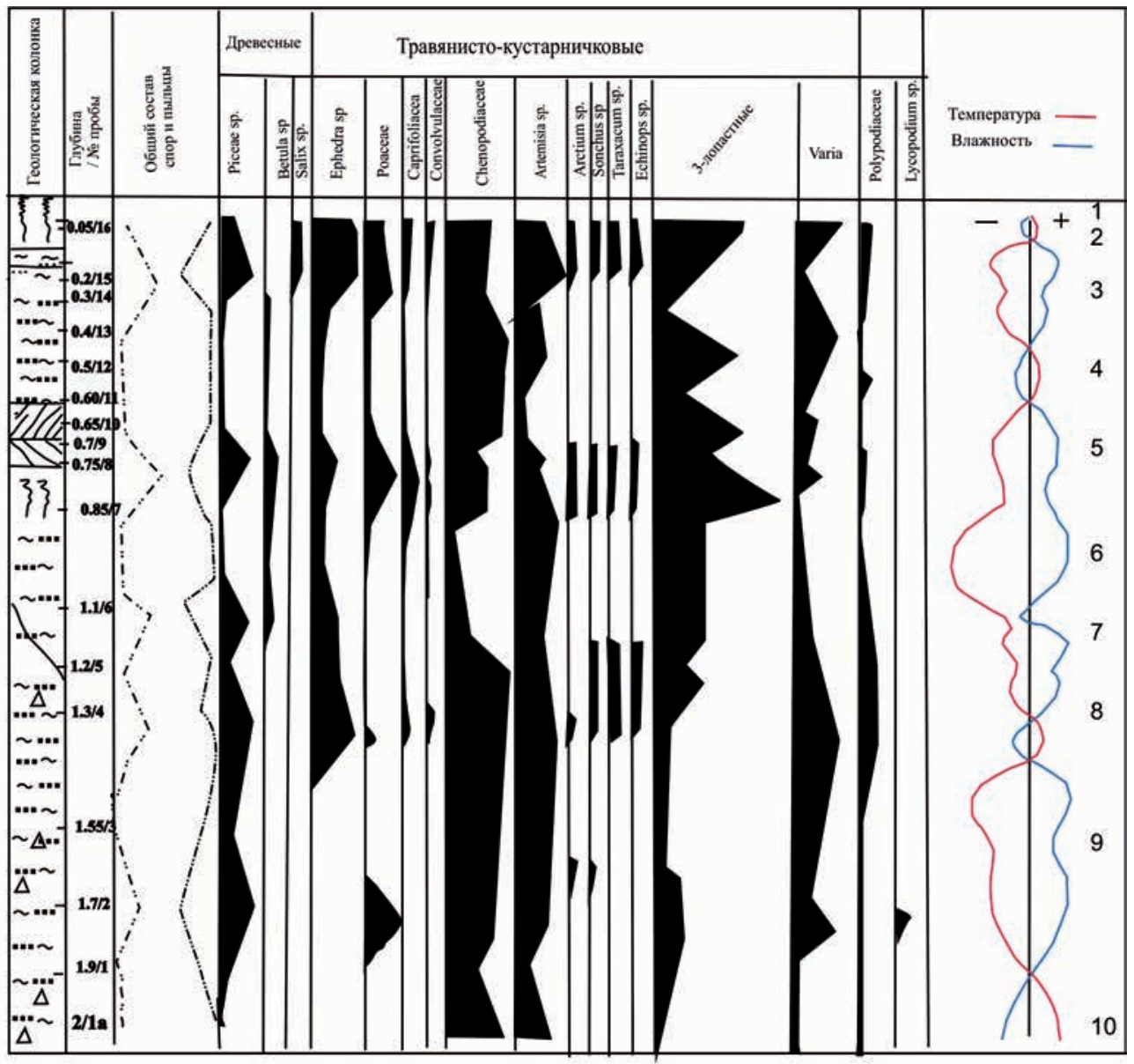

Рис. 10. Палинологическая диаграмма поселения Турген II

Fig. 10. Palynological diagram of the Turgen II settlement

На глубине 1,1 м были установлены лишь единичные, сильно поврежденные пыльцевые зерна ели (?), полыни, маревых. По-видимому, это может быть связано со значительным похолоданием.

Глубина 1,32-1,42 м. Установлены пыльцевые зерна ели, травянистые формы представлены пыльцой сложноцветных (с доминированием полыней) и маревых. Климатические условия, по-видимому, были несколько более теплыми и влажными, чем современные.

Глубина 1,46-2,00 м. Древесных почти нет (единично - в пробе 2
(1,6 м) пыльца ели), пыльца травянистых форм также встречена спорадически и в угнетенном состоянии. Это обстоятельство можно связать со значительным понижением температур и увеличением количества осадков, основная часть которых выпадала в виде снега, что и приводило к уменьшению благоприятных условий для созревания пыльцы растений. Вероятно, в это время происходило смещение вниз границ леса и расширение нивального пояса гор.

В 2018 г. на палинологический анализ были опробованы два шурфа из раскопа 2 поселения Кызылбулак- 
Аубекеров Б.Ж., Нигматова С.А. Геоархеологические исследования археологических объектов ...

IV: шурф 1 - с гл. 140 см до дневной поверхности и шурф 2 - до 80 см глубиной.

\section{Шурф 2}

Первый этап (современный 0-15 см) характеризуется богатым спорово-пыльцевым спектром с преобладанием пыльцы травянистой растительности, древесные (хвойные, в основном Picea sp., а также берез, ивы) составляют $15 \%$ от общего количества пыльцы в спектре (всего насчитано 400 пыльцевых зерен). Травянистые растения представлены мезофильным разнотравьем, и в основном, трехборозной ${ }^{2}$ пыльцой до $11 \%$, пыльцой маревых $6 \%$, сложноцветных - 32\%, среди которых установлена пыльца полыней, одуванчиков, осота, чертополоха, тысячелистника. Также в меньшем количестве определена пыльца лютиковых, бобовых, гераниевых, гвоздичных; однодольных: эремурус, лук, злаки.

Второй этап (глубина 15-35 см) характеризуется почти полным отсутствием пыльцы и спор, в препаратах масса фрагментов органики, почвенные грибы, водорослеподобные формы, споры папоротников.

Третий этап (35-55 см) аналогичен второму, но наблюдается большое количество углей, обугленных растительных тканей.

Четвертый этап (55-75 см) характеризуется обедненными в качественном и количественном отношении палиноспектрами. Установлена единичная пыльца ивы, березы, хвойных, вяза. В целом, количество пыль- цы древесных не превышает 5-7\%. Травянистые составляют 95-93\% и представлены трехбороздной пыльцой (до $70 \%$ от общего числа травянистых), маревыми, полынями, злаками. В спектрах установлены споры папоротников. Климат, вероятно, был холодным и влажным.

Пятый этап (глубина 75-90 см) близок по составу к третьему этапу: здесь также установлена масса обугленных растительных остатков, пыльцы мало, в основном это трехбороздная пыльца, неопределенного таксономического состава, единична пыльца ели Picea sp., Artemisia sp., Chenopodiaceae, Poaceae.

Шурф 1, глубина 140 см.

Шестой этап (90-110 см) характеризуется значительным увеличением содержания пыльцы елей Piceae sp. до $34 \%$, что свидетельствует о значительном расширении зоны хвойных лесов по сравнению с современным состоянием. Также среди древесных установлена единичная пыльца ивы. Травянистые составляют $65 \%$ от общего числа сосчитанных пыльцевых зерен и представлены: маревыми $45 \%$, гвоздичными - 10\%, сложноцветными (осот, одуванчик, тысячелистник), злаковыми, вьюнковыми, цикориевыми, эфедрой, которые вместе составляют 10\%. На долю спор папоротникообразных приходится $1 \%$.

Климат времени накопления данных отложений, вероятно, был достаточно благоприятен для жизни в этом районе: было теплее и более влажно, чем в настоящее время.

${ }^{2}$ Как правило, к «трехпоровым» формам относят пыльцу двудольных травянистых растений, таксономическую принадлежность которой невозможно определить, т.к. нет каких-либо характерных видовых признаков. Возможно, это недозрелая, недоразвитая пыльца полыни, бобовых и др. растений. Часто встречается в палиноспектрах аридной зоны Центральной Азии. 


\section{ҚАЗАҚСТАН АРХЕОЛОГИЯСЫ № 1 (11) 2021}
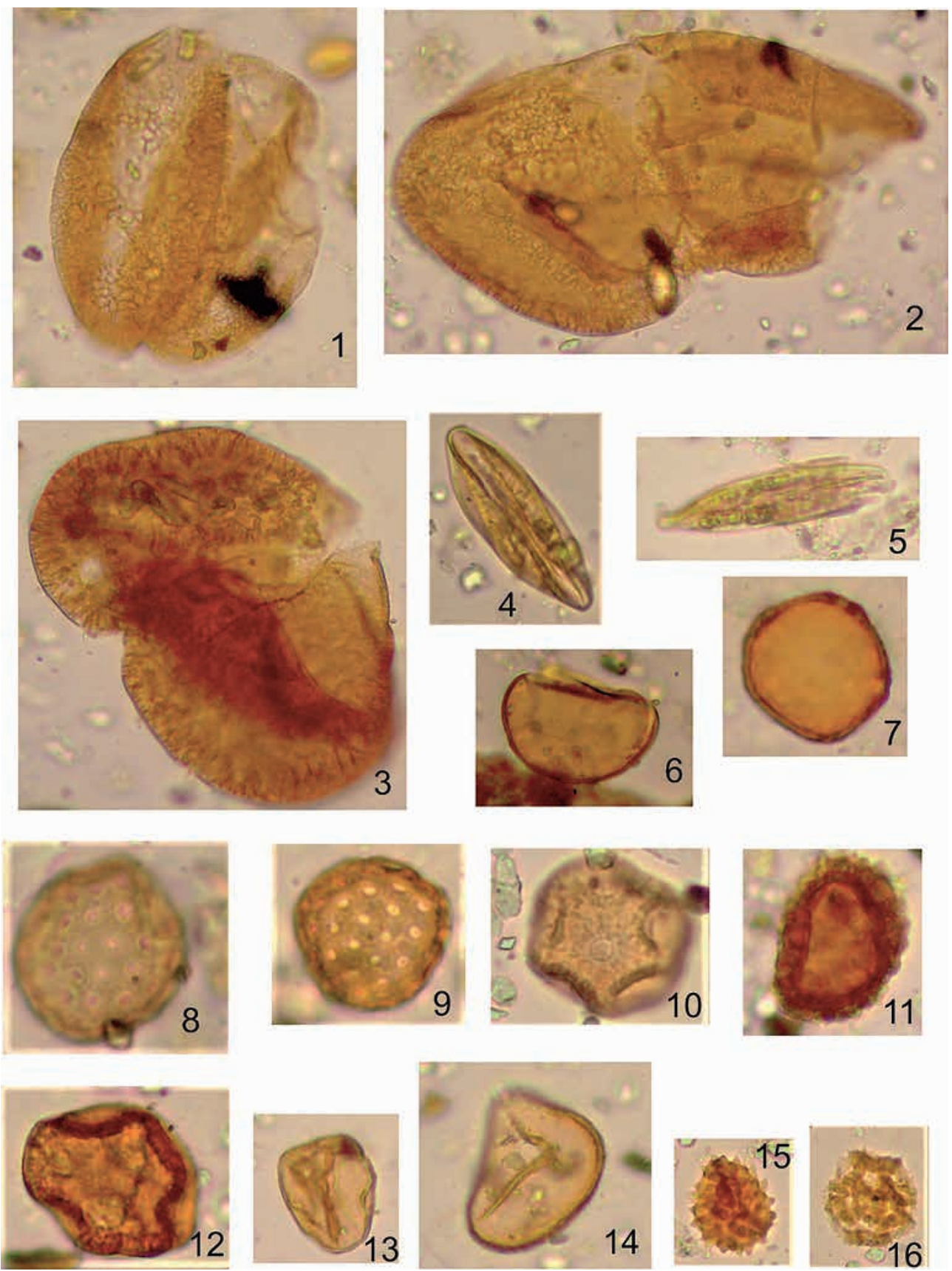

Рис. 11. Пыльияа и споры из отложений поселения Кызылбулак-IV: 1, 2, 3 - Piceae sp.; 4, 5 -Ephedra sp.; 6, 11 - Polypodiacae; 7 -Ulmus sp.; 8, 9-Chenopodiaceae; 10, 12 - Gipsophilla sp.; 13, 14 - Poaceae; 15 -Asteraceae; 16 -Cichorium sp

Fig. 11. Pollen and spores from the deposits of the Kyzylbulak-IV settlement: 1, 2, 3 -Piceae sp .; 4, 5-Ephedra sp .; 6, 11-Polypodiacae; 7 -Ulmus sp .; 8,9-Chenopodiaceae; 10, 12 - Gipsophilla sp .; 13,14-Poaceae; 15 -Asteraceae; 16 - Cichorium $s p$ 


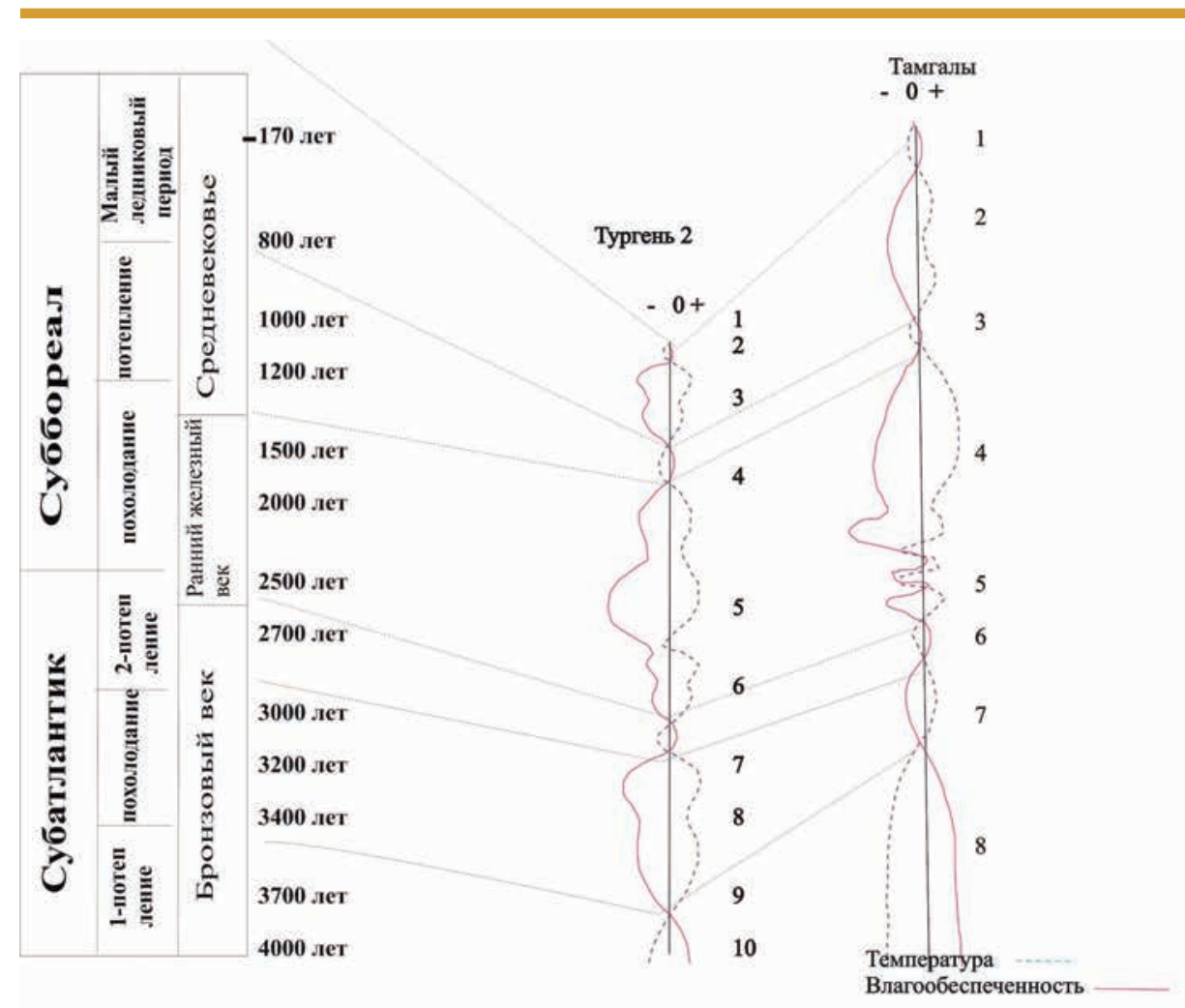

Рис. 12. Схема корреляичи событий в горах (Турген) и пустынной зоне (Тамгаль)

Fig. 12. Correlation scheme of events in the mountains (Turgen) and the desert zone (Tamgaly)

Седьмой этап (глубина 110120 см) характеризуется достаточно небогатым спорово-пыльцевым спектром, с доминированием пыльцы травянистых растений. Однако здесь практически не встречается пыльца хвойных, а состав споровых становится богаче, что косвенно свидетельствует о смещении границ леса вниз и расширении альпийских лугов. Вероятно, климат становился более холодным вследствие расширения оледенения в горах.

Восьмой этап (глубина 120135 см) аналогичен шестому. Здесь также установлена пыльца хвойных (10-17\%), доминируют травянистые, среди которых маревые составляют до $25 \%$, практически в таких же ко- личествах встречена пыльца трехбороздная (неустановленной таксономической принадлежности). Кроме того, встречена пыльца полыней (около 15\%), сложноцветных, цикориевых, валериановых, губоцветных, луков, лилейных, злаков (единично).

Девятый этап (глубина 135145 см). Здесь пыльца практически отсутствует, встречены единичные пыльцевые зерна зонтичных, злаков, трехбороздной пыльцы. Климат, вероятно, стал более холодным и сухим.

\section{Bblвodbl}

Сравнение климатических кривых голоценовых отложений долины реки Турген и археологического па- 
мятника Тамгалы, расположенного в пустынной зоне и имеющего несколько абсолютных дат, позволили провести их сопоставление. В бронзовом и раннем железном веках состав растительности в горах Иле Алатау был в основном близок к современному. Однако, климатические колебания вызывали изменения границ ландшафтных зон в горах, которые могли существенно влиять на условиях жизни народов того времени.

Климатические изменения наибольшее влияние оказывали на распределение зимних и летних температур, что создавало эффект, близкий к плювиальным и аридным фазам климатов.

Колебания климата от жаркогосухого до холодного-влажного существенно изменяли активизацию про- цессов осадконакопления. В течение бронзового века процессы осадконакопления в аридной зоне были очень незначительными, что позволяло использовать нижние части склонов положительных форм в качестве мест проживания [Аубекеров и др., 2001, с. 26-34; Нигматова, 2002, с. 171-172; 2008, c. 4-15].

В раннем железном веке в условиях большей увлажненности эрозионные процессы усиливались и предопределили передислокацию некрополей и поселений на плоские вершины положительных форм. Практически лишенная растительности и сложенная рыхлыми отложениями морена являлась удобным для жизни местом, безопасным и достаточно увлажненным в аридные этапы.

\section{ЛИТЕРАТУРА}

1. Аубекеров Б.Ж., Нигматова С.А. Приложение 1. Геолого-геоморфологические и палинологические исследования верховьев ущелья Киши-Турген // Горячев А.А. Древний археологический комплекс верховьев ущелья Киши-Турген. Монография / отв. ред. Г.С. Джумабекова. Алматы: Институт археологии им. А.Х. Маргулана, 2020. C. $241-250$.

2. Аубекеров Б.Ж., Сала Р., Нигматова С.А., Жакупова Ш.А. Палеоклиматические условия аридной зоны Семиречья в эпоху бронзового и раннего железного веков // Природные и социальные проблемы географии аридных территорий: м-лы Жандаевских чтений (г. Алматы, 20-22 мая 2001 г.). Алматы: Институт геологических наук им. К.И. Сатпаева, 2001. С. 26-34.

3. Бажанов О.В. Заилийский район // Геология СССР. Южный Казахстан. Кн. 1. Геологическое описание. М.: «Недра», 1971. Т. 40. С. 509-516.

4. Волкова Е.A. Джунгаро-Северотяньшанская провинция // Ботаническая география Казахстана и Средней Азии (в пределах пустынной области) / под ред. Рачковской Е.И., Волковой Е.А., Храмцова В.Н. СПб.: б/и, 2003. С. 217-219.

5. Горячев A.A. Древний археологический комплекс верховьев ущелья КишиТурген. Монография / отв. ред. Г.С. Джумабекова. Алматы: Институт археологии им. А.Х. Маргулана, 2020. 260 с.

6. Костенко Н.Н. Четвертичная система // Геология СССР. Южный Казахстан. Кн. 1. Геологическое описание. М.: «Недра», 1971. Т. 40. С. 494-522.

7. Костенко Н.Н. Четвертичные отложения Казахстана и прилегающих территорий союзных республик. Алма-Ата: Министерство геологии КазССР, 1978. 157 с. 1965. $216 \mathrm{c}$.

8. Куприянова Л.А. Палинология сережковидных (Amentiferae). М.-Л.: Наука, 
Аубекеров Б.Ж., Нигматова С.А. Геоархеологические исследования археологических объектов ...

9. Куприянова Л.А., Алешина Л.А. Пыльца и споры растений флоры европейской части СССР. Л.: Наука, 1972. Т. 1. 172 с.

10. Куприянова Л.А., Алешина Л.А. Пыльца и споры растений флоры европейской части СССР. Л.: Наука, 1978. Т. 2. 184 с.

11. Моносзон M.X. Описание пыльцы представителей семейства Ulmaceae, произрастающих на территории СССР // Работы по спорово-пульцевому анализу. М.: Издво АН СССР, 1959. Вып. 77. С. 187-198.

12. Нигматова С.А. Палинологическая характеристика культурных слоев эпохи бронзы и раннего железного века Семиречья (Юго-Восточный Казахстан) // Методические аспекты палинологии: м-лы Х Всерос. палинол. конф. (г. Москва, 14-18 октября 2002 г.). М.: Российская Академия наук, 2002. С. 171-172.

13. Нигматова С.A. Климатостратиграфия голоцена аридной зоны Казахстана // Известия НАН РК. Сер. Геол. 2008. № 5. С. 4-15.

14. Рачковская Е.И., Волкова Е.А., Храмцов В.Н. (ред.) Ботаническая география Казахстана и Средней Азии (в пределах пустынной области). СПб.: б/и, 2003. 424 с.

15. Чупина Л.Н. Палинологическая характеристика позднеплейстоценовых отложений Центрального и Южного Казахстана // Известия АН КазССР. Сер. геол. 1978. № 3. С. 58-63.

16. Шльгин А.Е. Основные черты геологического строения // Геология СССР. Южный Казахстан. Кн. 1. Геологическое описание. М.: «Недра», 1971. Т. 40. С. 23-29.

\section{REFERENCES}

1. Aubekerov, B. Zh., Nigmatova, S. A. 2020. In: Jumabekova, G. S. (ed.). Goryachev, A. A. Drevniy arheologicheskiy kompleks verhoviev ushcheliya Kishi-Turgen (Ancient archaeological complex in the upper reaches of the gorge Kishi-Turgen). Almaty: A. Kh. Margulan Institute of Archeology, 241-250 (in Russian).

2. Aubekerov, B. Zh., Sala, R., Nigmatova, S. A., Zhakupova, Sh. A. 2001. In: Jandayevskie chteniya (Jandayev reading). Almaty: K.I. Satpayev Institute of Geology, 2634 (in Russian).

3. Bazhanov, O. V.1971. In: Geologiya SSSR. Yuzhnyi Kazahstan. Kn. 1. Geologicheskoe opisanie (Geology of the USSR. South Kazakhstan. Book 1. Geological description). Moscow: "Nedra" Publ. T. 40, 509-516 (in Russian).

4. Volkova, E. A. 2003. In: Rachkovskaya, E. I., Volkova, E. A., Khramtsov, V. N. (eds.). 2003. Botanicheskaya geografiya Kazahstana i Sredney Azii (v predelah pustynnoy oblasti) (Botanical geography of Kazakhstan and Central Asia (within the desert region)). Saint Petersburg, 217-219 (in Russian).

5. Goryachev, A. A. 2020. Jumabekova, G. S. (ed.). Drevniy arheologicheskiy kompleks verhoviev ushcheliya Kishi-Turgen (Ancient archaeological complex in the upper reaches of the gorge Kishi-Turgen). Almaty: A. Kh. Margulan Institute of Archeology (in Russian).

6. Kostenko, N. N. 1971.In: Geologiya SSSR. Yuzhnyi Kazahstan. Kn. 1. Geologicheskoe opisanie (Geology of the USSR. South Kazakhstan. Book 1. Geological description). Moscow: "Nedra" Publ. T. 40, 494-522 (in Russian).

7. Kostenko, N. N. 1978. Chetvertichnye otlozheniya Kazahstana i prilegayushchih territoriy soyuznyh respublik (Quaternary deposits of Kazakhstan and adjacent territories of the union republics). Alma-Ata: Ministerstvo geologii KazSSR (in Russian).

8. Kupriyanova, L. A. 1965. Palinologiya serezhkovidnyh (Amentiferae) (Amentiferae palynology). Moscow-Leningrad: "Nauka" Publ. (in Russian)

9. Kupriyanova, L. A., Aleshina, L. A. 1972. Pyltsa i spory rasteniy flory evropeyskoy chasti SSSR (Pollen and plant spores of the flora of the European part of the USSR). Leningrad: "Nauka" Publ. T. 1 (in Russian). 
10. Kupriyanova, L. A., Aleshina, L. A. 1978. Pyltsa i spory rasteniy flory evropeyskoy chasti SSSR (Pollen and plant spores of the flora of the European part of the USSR). Leningrad: "Nauka" Publ. T. 2 (in Russian).

11. Monoszon, M. Kh. 1959. In: Raboty po sporovo-pulcevomu analizu (Works on spore-pulse analysis). Moscow: Izd-vo AN SSSR, 77, 187-198 (in Russian).

12. Nigmatova, S. A. 2002. In: Metodicheskie aspekty palinologii (Methodical aspects of palynology). Moscow: Russian Academy of Sciences Publ., 171-172 (in Russian).

13. Nigmatova, S. A. 2008. In: Izvestiya NAN RK. Ser. Geol. (Bulletin of the National Academy of Sciences of the Republic of Kazakhstan. Geological Series), 5, 4-15 (in Russian).

14. Rachkovskaya, E. I., Volkova, E. A., Khramtsov, V. N. (eds.). 2003. Botanicheskaya geografiya Kazahstana i Sredney Azii (v predelah pustynnoy oblasti) (Botanical geography of Kazakhstan and Central Asia (within the desert region)). Saint Petersburg (in Russian).

15. Chupina, L. N. 1978. In: Izvestiya AN KazSSR. Ser. geol. (Bulletin of the Academy of Sciences of the Kazakh SSR. Geological Series), 3, 58-63 (in Russian).

16. Shlygin,A. E. 1971. In: Geologiya SSSR. Yuzhnyi Kazahstan. Kn. 1. Geologicheskoe opisanie (Geology of the USSR. South Kazakhstan. Book 1. Geological description). Moscow: "Nedra" Publ. T. 40, 23-29 (in Russian).

Мүдделер қақтығысы туралы ақпаратты ашу. Авторлар мүдделер қақтығысының жоқтығын мәлімдейді. / Раскрытие информации о конфликте интересов. Авторы заявляют об отсутствии конфликта интересов. / Disclosure of conflict of interest information. The authors claims no conflict of interest.

Мақала туралы ақпарат / Информация о статье / Information about the article.

Редакцияға түсті / Поступила в редакцию / Entered the editorial office: 05.04.2021.

Рецензенттер мақұлдаған / Одобрено рецензентами / Approved by reviewers: 12.04.2021.

Жариялауға қабылданды / Принята к публикации / Accepted for publication: 19.04.2021. 